\title{
KÖZFOGLALKOZTATÁS, MINT A MUNKANÉLKÜLISÉG CSÖKKENTÉSÉRE ALKALMAS EGYSÉGES RENDSZER BEMUTATÁSA
}

\begin{abstract}
Oláh Judit
SUMMARY

It is important to investigate labour market tools as employment policy is expected to reduce unemployment and the segmentation of the labour market, to decrease the intensifying unfavourable situation of vulnerable social groups, to help the geographical, employment and branch labour mobility and to improve productivity. I examine the role of public employment of the labour market tools. I introduce the development of public employment tools and detail that what effects the public employment has on the tendency of unemployment. The literature review in my research was compiled with the aim of a secondary research objective. In the literature review I deal with the introduction of the public employment as a tool for handling labour market crises in the countries of the European Union, as well as with the characteristics of the new system of public employment in Hungary. The numbers of those who are involved in the public employment program both at national and sub-regional levels forecast its significance and necessity under the present condition of the Hungarian economy.
\end{abstract}

\section{BEVEZETÉS}

A munkanélküliség és a foglalkoztatottság problémája világszerte növekvő aggodalmat váltott ki. Az aggódás és a megoldások kilátásaival kapcsolatos pesszimizmus a világ számos részére jellemző manapság.

A legtöbb fejlett országban 1973 óta folyamatosan nött a munkanélküliség átlagos szintje, az OECD országokban jelenleg 10\% körül van. Ezen túlmenően aggodalomra ad okot, hogy megmarad ezen a magas szinten, valamint az is probléma, hogy a szakképzetlen dolgozók foglalkoztatási kilátásai rendkívül rosszak, és ezzel összefüggésben növekednek a béregyenlötlenségek a szakképzett és a szakképzetlen dolgozók között. Ahogyan a leírtakból is látható, a nagyarányú munkanélküliségből egy sor további probléma következik: növekvő mértékü egyenlötlenség és társadalmi kirekesztettség, az elmaradt termelés és az elvesztegetett emberi erőforrások, növekvő gazdasági bizonytalanság, és a munkanélkülieknek okozott emberi szenvedések.

Az előbbiek együttesen jelennek meg a Cloke és Park (1985) által kidolgozot háromszintủ humán erőforrás hierarchiában. Ebben a szisztémában az emberek és közösségeik életminöségét alapvetöen meghatározzà a rendelkezésre álló munkaerö mennyisége és minősége, valamint a munka hozzáférhetősége, azaz a helyben és az ingázással elérhető munkahelyek megléte (Kis 2008).

A Közép- és Kelet-Európa - így hazánk is -, korábban központi tervutasításos rendszerben müködö gazdaságokat az átmenet folyamatának első éveiben a kibocsátás nagyarányú visszaesése, a munkaerő piac kedvezőtlen alakulása Bácsné (2014) a tömeges munkanélküliség gyors kialakulása, valamint fokozódó egyenlötlenség és növekvő szegénység jellemezte. Bár 1994-ben néhány országban már relatív javulás mutatkozott, a kilátások továbbra is rosszak. Összességében a 
piacgazdaságra való átalakulás folyamata nehezebbnek bizonyult, mint ahogy az elöre látható volt. Azt is láthatjuk azonban, hogy hazánkban voltak olyan vállalkozások, amelyek akár önerős, akár pályázati úton elnyerhető források igénybe vételével eredményesebbé tették tevékenységüket, így képesek voltak a dolgozói létszámukat növelni (Vántus 2010). A nagymértékben torzult gazdaságok szerkezetének átalakítása, amelyek évtizedeken át el voltak szigetelve, mind a hazai, mind a nemzetközi piaci erőktől, és az új piaci intézmények nulláról történő kiépítése valóban ijesztő és időigényes feladatnak bizonyult.

Tehát fontos feladat, hogy megerősítsék a munkaerőpiaci politika eszközeit. Az aktív munkaerő-piaci programok megvalósításához szükséges a kapacitásokat és munkaerőpiaci szolgáltató szervezetet erösíteni. Mivel ez biztosíthatja a munkaerő „újra bevetéséhez” alkalmazott eszközök hatékonyságának növelését, ami a folyamatban lévő gazdasági szerkezetváltás adott nagyságrendje mellett kritikus jelentőségü.

\section{A KÖZFOGLALKOZTATÁS TÖRTÉNELMI MÚLTJA ÉS FEJLŐDÉSI TENDENCIÁJA}

A tömeges munkanélküliség a XVIII. század végén megkezdődött ipari forradalom terméke: a gépek térhódításával egyre kevésbé volt szükség az emberi munkára, izomerőre. A munkanélküliség számos társadalmi problémához, feszültséghez vezetett. A megoldáskeresés okán a XIX. század végére szemléletváltozás ment végbe Európa-szerte, mely szerint a munkaképes ember nyomora nem magánügy többé. A munkanélküli társadalmi kategória lett, mellyel foglalkoznia kell a kormányzatoknak (Gyáni 2011). A kormányzati intézkedések egyik lehetősége a nagy létszámúvá és tartóssá váló munkanélküliség ellen - a folyamatos segélyezés helyett - a közpénzekböl, közérdeket szolgáló feladatok elvégzése, arra rászoruló emberek foglalkoztatásával.

Ulicska (1997) „A munka, mint büntetés” írásában megemlíti, hogy az országban a századelőn az egyre növekvő munkanélküliség mellett látszólag előállt az a furcsa helyzet, hogy a társadalom ugyanazzal büntetett, amivel jutalmazott. Jól érzékelhető a változás a szinonimákkal: a dolgozó házakból előbb dologházak, majd kényszermunkaházak lettek. Ez a gondolat sokakban felmerül a jelenkori közfoglalkoztatással kapcsolatosan is, a ma müködtetett rendszernek is létező kettőssége. Azok a munkafeladatok, amelyeket ma az önkormányzatok által szervezett közfoglalkoztatási programok keretében elvégeznek a bevont álláskeresők, sok esetben megegyeznek a közérdekủ munkára ítélt szabálysértést elkövetők által elvégzendő feladatokkal. A helyzet kettőssége, amit Ulicska (1997) is felveti, hogy ugyanazt a munkát az egyik ember ,jutalomként" végzi, míg a másik „büntetésként”, ez morális szempontból kérdéses. Vajon milyen hatással van ez a közfoglalkoztatás presztízsére? Itt utalnék Csoba (2010a) „Segély helyett munka" írására, mely szerint a mai közfoglalkoztatási programok sok hasonlóságot mutatnak a középkori dologházak müködését meghatározó filozófiával. Mindkettő megvalósítását áthatja a kényszer. Nincs választási lehetősége a megszólítottnak arra vonatkozólag, hogy részt kíván-e venni a programban. További közös 
vonásként említi azt, hogy az elvégzett munkáért jóval alacsonyabb jövedelem jár, mint az elsődleges munkaeröpiacon.

Csoba (2010a), Csoba (2010b) és Ulicska (1997) írásainak kapcsán tovább kutakodtam, és néhány szóval visszautalnék a közfoglalkoztatás történetére. Ezt azért tartom fontosnak, mert ez hủen tükrözi a munkanélküliséggel kapcsolatos álláspontok alakulását a XVI. századra visszanyúlóan, amikor is - az 1555-ös évben elsőként - Amszterdamban létrehozták az első dologházat. Feljegyzések szerint Magyarországon körülbelül 150 éven keresztül, a XVIII. századtól a második világháború kitöréséig, müködtek ilyen jellegủ intézmények. A dologházakba azokat az embereket zárták, akik nem fogadták el a kapitalista társadalom rendjét, renitens viselkedést tanúsítottak. Csavargók és koldusok, akik nem akartak beilleszkedni egy olyan társadalomba ahol a tulajdonjog alapja a munka. Ezeknek az intézményeknek eleinte a munkáltatás mellett nevelési, erkölcsnemesítő célzata is volt, később már csak nagyon szigorú fegyelem mellett a kötelezö munkavégzés volt a meghatározó, határozott vagy határozatlan időtartamra, a kriminalitás csökkentése érdekében.

\subsection{KÖZHASZNÚ FOGLALKOZTATÁS}

A közhasznú munkavégzésre korábban nyújtott támogatás a lakosságot vagy a települést érintő közfeladat, vagy az önkormányzat által önként vállalt, a lakosságot illetőleg a települést érintő feladat ellátását, vagy közhasznú tevékenység folytatását támogatta. A közhasznú munkavégzés fajtái voltak a kommunális, az egészségügyi és szociális, a müvelödési és oktatási, valamint egyéb tevékenységek.

A részletes feltételeket a foglalkoztatás elősegítéséröl és a munkanélküliek ellátásáról szóló 1991. évi IV. Törvény felhatalmazása alapján a 6/1996. (VII. 16.) MüM rendelet szabályozta, azonban az egyes szociális, gyermekvédelmi, családtámogatási, fogyatékosságügyi és foglalkoztatási tárgyú törvények módosításáról szóló 2010. évi CLXXI. Törvény egyes szociális, gyermekvédelmi, családtámogatási, fogyatékosságügyi és foglalkoztatási tárgyú törvények módosításáról hatályon kívül helyezte.

A közfoglalkoztatási formák mindegyike évtizedek óta kitölt egy kis rést a munkaeröpiac palástján. Csehné (2007) alapján a közhasznú foglalkoztatás 1987. második félévétől mủködött Magyarországon. Célja az átmeneti jövedelemhiány pótlása volt, mert mindenki abban bízott, hogy majd újra beindul az ipar, a privatizáló tulajdonosok új piacokat fedeznek fel, és azzal, hogy új piacokra kezdenek el termelni, a munkanélküliek ismét foglalkoztatottakká válnak. A tartós munkanélküliek munka világában történő megjelenésének szinte egyetlen formájaként a közhasznú munka müködött. Kezdetben viszonylag szükebb volt és föként a megélhetésüket csak ilyen formában biztosítani tudókat érintette. Olyan munkakörökre szervezték meg az önkormányzatok, amelyet más munkaerővel nem tudtak betölteni és elvégeztetni. A közhasznú támogatás igénybevételével az önkormányzatok többségében településtisztasági, közterület karbantartási parkfenntartási és belterületi vízrendezési feladatokat oldottak meg (I2, I3, I4). 


\subsection{KÖZMUNKA}

Az állami és önkormányzati közfeladatok ellátására a közhasznú foglalkoztatást követő közfoglalkoztatási forma, amely közel fél évszázad elteltével, 1996-ban jelent meg újra, a közmunka volt.

A közmunka kategóriájába a munkanélküliség csökkentésére alkalmas fejlesztési, felújítási, különösen infrastrukturális és környezetvédelmi, továbbá az elmaradott térségek felzárkóztatását célzó, önkormányzati és egyéb társadalmilag hasznos közfeladatok ellátásának javítására irányuló, erre a célra a költségvetésben elkülönített állami pénzeszközböl támogatott programok tartoztak. A programok szervezésének fó célja az volt, hogy a hosszabb ideje munkát nem találó, szociális segélyre jogosult álláskeresők átmeneti foglalkoztatását önkormányzati, közösségi célú feladatok ellátásával valósítsák meg. A támogatás alanya lehetett kistérségenként egy, jogi személyiséggel rendelkező kistérségi önkormányzati társulás, vagy a társulás által felhatalmazott tag-települési önkormányzat (gesztor), közhasznú társaság, valamint területfejlesztési tanács.

A részletes szabályokat a 49/1999. (III.26.) Kormányrendelet tartalmazta, a 375/2010. (XII.31.) Kormányrendelet a támogatási formát hatályon kívül helyezte. Országosan jellemzö volt, hogy a közmunkában foglalkoztatott személyek többsége férfi volt. Ennek okaként föként az elvégzendő munka jellege volt megnevezhetö, hiszen legtöbb esetben nehéz fizikai munkát kellett elvégezni, az árvízvédelem, katasztrófa elhárítás, közútfenntartás a vasútkarbantartás területén (Kulinyi 2013).

\subsection{KÖZCÉLÚ MUNKA}

A közcélú munka, 2000 májusától hivatott felhasználási kötöttségek mellett, költségvetési forrásból munkalehetőséget biztosítani a rendszeres szociális segélyben részesülöknek. A közcélú munka olyan közmunkának vagy közhasznú munkának nem minősülő állami vagy helyi önkormányzati feladat ellátását jelentette, amelynek teljesítéséről - jogszabály alapján - a települési önkormányzatnak kellett gondoskodnia. A közcélú foglalkoztatást a települési önkormányzat szervezte a költségvetésböl biztosított, felülröl nyitott keretböl.

A közcélú munka részletes feltételeit a szociális igazgatásról és a szociális ellátásokról szóló 1993. évi III. Törvény szabályozta, amelyet az egyes szociális, gyermekvédelmi, családtámogatási, fogyatékosságügyi és foglalkoztatási tárgyú törvények módosításáról szóló 2010. évi CLXXI. Törvény egyes szociális, gyermekvédelmi, családtámogatási, fogyatékosságügyi és foglalkoztatási tárgyú törvények módosításáról hatályon kívül helyezte.

2001-ben vezették be hazánkban, és ugyanúgy a közfoglalkoztatás két pillérét, a segélyezettek szürését és ellátási jogosultságának megszerzését segíti, továbbá az önkormányzatok közfeladatainak költségtakarékos ellátását szolgálja (Galasi-Nagy 2003). Nemzetközi szinten ehhez hasonló, kiterjedt nemzeti programok szervezése föleg az északi és a kontinentális Európára jellemző. Bizonyos kritériumok mellett bárki részt vehet bennük, és olyan univerzális eszközök, amelyekben a célcsoport 
egyszerre csak egyféle kezelést kap, függetlenül a résztvevők heterogén paramétereitől. A célkitüzésük gyakran homályos, amelyek az intézkedés sikerességét is megkérdőjelezhetik (Hudomiet-Kézdi 2008).

\section{4. ÚT A MUNKÁHOZ PROGRAM}

A program 2009. január 1-jétől indult és a közmunka rendszerének 2011. január 1jétől történő megváltozásáig tartott.

Kiemelt célja, hogy a munkára képes, tartósan munkanélküli személyek - akik 2008. évig egy típusú ellátásban, rendszeres szociális segélyben részesültek, 2009től pedig rendelkezésre állási támogatásban vagy rendszeres szociális segélyben - a korábbiaknál fokozottabb mértékben vegyenek részt valamely közfoglalkoztatási formában, annak érdekében, hogy rendszeres munkajövedelemhez jussanak. Az alacsony iskolai végzettségủ munkavállalók számára ugyanis a nyílt munkaeröpiacra való visszakerülés első lépcsőjét a közfoglalkoztatásban való részvétel jelentheti. Azoknak a személyeknek, akik életkorukból, egészségi állapotukból, sajátos egyéni élethelyzetből adódóan nem tudnak munkát vállalni, nem kell részt venniük a közfoglalkoztatásban, és továbbra is kaphatják a rendszeres szociális segélyt.

A program célcsoportja a gazdaságilag nem aktív lakosság, a nyilvántartott álláskeresők és a szociális segélyből élők. A program céljai között szerepel az érintett csoportok visszavezetése a munkaerőpiacra, a munkahelyteremtést támogató projektek bővítése, és ezzel egy időben a feketemunka visszaszorítása. A program egyik elvárása és követelménye, hogy azokat, akik 35 év alattiak és nem végezték el a 8 osztályt, kötelező képzésben kell részesíteni. Országos szinten 90 ezer ember foglalkoztatása valósul meg a program keretein belül.

A program megindításától a közfoglalkoztatás meghatározó jelentőségüvé vált, bár ennek a programnak a megindítása még nem válságenyhítő célzattal történt. Ez az első év, amikor közfoglalkoztatás szervezése átkerült az önkormányzatoktól a munkaügyi kirendeltségekhez. A döntés, amely a közfoglalkoztatás koordinációját áthelyezte az önkormányzatoktól a munkaügyi szervezethez, több önkormányzat megitélése szerint nem volt kellően átgondolt és megalapozott. Ettől az évtől kezdődően, a települési önkormányzatoknak közfoglalkoztatási tervet kellett készíteniük az állami foglalkoztatási szolgálattal együttmüködve, egy évre elöre az elvégzendő feladatokról, azok időbeni ütemezéséről, létszámigényéről és költségigényéről. Az önkormányzatok nehezen fogadták el, hogy „elvették” az önálló döntési jogkörüket a közfoglalkoztatás szervezésében.

A célcsoportok demográfiai összetételét, iskolai végzettségét vizsgálva azt látjuk, hogy megoszlásuk a regisztrált munkanélküliekhez viszonyítva lényegesen kedvezőtlenebb. A bevontak jelentős hányada az idősebb korcsoportból kerül ki, és iskolai végzettség tekintetében felülreprezentáltak az iskolázatlanabbak. Ezzel összefüggésben alakult az ki, hogy a közfoglalkoztatási programokban végzett munka többnyire képzettséget nem igénylö fizikai munka (Kézdi 2011). Czomba (2010) kutatásában kiemelte, hogy a közfoglalkoztatás szükséges rossz, de csak 
ezáltal érhető el, hogy az embereket munkaképes állapotban tartsák mindaddig, amíg az elsődleges munkaerőpiacon el tudnak helyezkedni

Âttekintve az elmúlt két évtized alkalmazott eszköztípusait, lényegében nem lehet érdemi mennyiségi vagy minőségi fejlődést kimutatni a közfoglalkoztatás rendszerét illetően. A programok teljes menedzsmentje egy speciális apparátust igényelt, ugyanakkor lokális szereplök egy fokozatosan lecsupaszított központi forrásallokációval kellett, hogy szembenézzenek az évek során (Semjén 1996). A hazai közmunkaprogramok eredményeiről nagyon kevés szakirodalom számol be, hiszen kezdettől fogva a legalacsonyabb végzettségü, és hátrányos helyzetü munkanélküliek sorsának átmeneti javítására használták. Firle et al. (2007) felmérései szerint a résztvevők kisebb valószínủséggel (30-35\%) helyezkednek el, mint a kontrollcsoportba került nem segélyezett, munkaképes inaktív személyek, tehát a kutatók szerint nincs szignifikáns munkaerő-piacjavító hatása. Ugyanakkor a hátrányos helyzetü vidéki térségekben ez a munkaforma az egyetlen és átmeneti munkalehetőség, azonban tranzitív hatás, azaz a tartós foglalkoztatás elérésére egyáltalán nem alkalmas, mi több erösítheti a beragadás hatást (Hudomiet-Kézdi 2008, Bass 2010).

A közfoglalkoztatás korábbi gyakorlata nem volt hatékony. Szabályozásában, finanszírozásában és müködésében erösen széttagolt és átláthatatlan, költségeit és humánerőforrás felhasználását tekintve pazarló volt. Kevesen vállaltak el piaci alapú, nagyobb teljesítményt követelő munkát a versenyszférában.

A tapasztalatok egyértelmủen azt mutatták, hogy a közmunka program, a közcélú és közhasznú foglalkoztatás nem vezetett vissza az elsődleges munkaerőpiacra. Sokkal inkább egy olyan életstratégia kialakulását segítették elö, amely - a segélyekből élés mellett - az álláskeresőket passzivitásra ösztönözte.

A közfoglalkoztatás rendszerének átalakítására azzal a céllal került sor, hogy ezeket a problémákat orvosolja, valamint hogy az új támogatási rendszer segítségével minél több munkára képes és kész, aktív korú, munkaerőpiaci szempontból hátrányos helyzetủ személy számára biztosítsa a munka világába való visszatérést (Hoffman 2012).

\subsection{NEMZETI KÖZFOGLALKOZTATÁSI PROGRAM}

2011. január 1-jétől jelentősen átalakult a közfoglalkoztatás rendszere. Megszünt a közcélú illetve a közhasznú munkavégzés valamint a költségvetési szervezeteknél müködtetett és a munkanélküliek elhelyezkedését segítő közmunkaprogram. Helyettük jött létre a közfoglalkoztatási támogatások új rendszere, amely az álláskeresőknek, és kiemelten a foglalkoztatás helyettesítő támogatásban részesülőknek kíván átmeneti munkát biztosítani. Jelentős változást eredményezett a közfoglalkoztatás szempontjából, hogy 2011. szeptember 1. napjától bevezették a közfoglalkoztatási jogviszonyt (Bagó 2013). 2011. január 1-jével, az „Út a munkához" programot felváltva, a kormány meghirdette a Nemzeti Közfoglalkoztatási Programot, amelynek deklarált célja az értékteremtő közfoglalkoztatás jogi kereteinek megteremtése, és a munkaképes lakosság, az álláskeresők munkához juttatása, foglalkoztatásának elősegítése. 
A program további célja, hogy mindenkinek munkát adjon, aki dolgozni akar, és ezen keresztül, radikálisan leszorítsa a segélyezettek számát. Az új közfoglalkoztatási rendszerben - az eddigiektől eltérően - nem egy felülről nyitott elöirányzatból történik a támogatás finanszírozása. Ez biztosítja, hogy a program müködésére rendelkezésre bocsátott források területi eloszlása ne térjen el az eredetileg meghatározott arányoktól. Kiemelt cél, hogy azokban a földrajzi térségekben, ahol magas a regisztrált álláskeresők létszáma és kevés a munkalehetöség, több forrás jusson a közfoglalkoztatás keretében biztosítható munkavégzési lehetőségekre.

A közfoglalkoztatás megújult rendszerében a regisztrált aktív álláskeresők foglalkoztatása 2011. január 1. napjától az alábbi közfoglalkoztatási támogatási formák segítségével valósult meg:

- rövid időtartamú közfoglalkoztatás támogatása,

- hosszabb időtartamú közfoglalkoztatás támogatása,

- országos közfoglalkoztatási programok támogatása,

- közfoglalkoztatás mobilitását szolgáló támogatás.

2011. szeptember 1. napján hatályba léptek:

- a közfoglalkoztatásról és a közfoglalkoztatáshoz kapcsolódó, valamint egyéb törvények módosításáról szóló 2011. évi CVI. Törvény közfoglalkoztatásra vonatkozó rendelkezései,

- a közfoglalkoztatási bér és a közfoglalkoztatási garantált bér megállapításáról szóló 170/2011. (VIII. 24.) Kormányrendelet, valamint

- a közfoglalkoztatáshoz nyújtható támogatásokról szóló 375/2010. (XII. 31.) Kormányrendelet módosításai is.

Az új típusú közfoglalkoztatás lényeges eleme, hogy a támogatások - pályázati eljárás helyett - kérelemre igényelhetők, valamint az is, hogy a foglalkoztatás az újonnan létrejött közfoglalkoztatási jogviszony keretében történhet.

A közfoglalkoztatási jogviszony - mint a Munka Törvénykönyvének hatálya alá tartozó speciális munkaviszony - időtartama alatt a közfoglalkoztatott társadalombiztosítási szempontból biztosítottnak minősül: pénzbeli és természetbeni egészségbiztosítási ellátásra jogosult, közfoglalkoztatásban töltött ideje beleszámít az öregségi nyugdíjra jogosító szolgálati időbe. A közfoglalkoztatási jogviszonyra a munkaviszonyra irányadó adózási és munkavédelmi szabályokat kell alkalmazni.

A közfoglalkoztatás ideje alatt munkaerőpiaci szolgáltatást és képzési támogatást vehetnek igénybe a közfoglalkoztatottak, hogy a megszerzett gyakorlat birtokában a határozott idejủ közfoglalkoztatást követően, munkát tudjanak vállalni az elsődleges munkaeröpiacon.

$\mathrm{Az}$ új rendszerhez szervezeti átalakulás is társult: az egyes miniszterek, valamint a Miniszterelnökséget vezető államtitkár feladat- és hatásköréről szóló 212/2010. (VII. 1.) Kormányrendelet 37. § w. pontja a belügyminiszter szakpolitikai feladatés hatáskörébe utalta a közfoglalkoztatást, ennek megfelelöen a Belügyminisztériumban létrejött a Közfoglalkoztatási Helyettes Államtitkárság. A Közigazgatási és Igazságügyi Minisztériummal együttműködve a Nemzetgazdasági 
Minisztérium a munkaügyi központok állományában kijelölte azokat a referenseket, akik - a belügyminiszter szakmai irányításával - területi, illetve helyi szinten látják el a közfoglalkoztatással kapcsolatos feladatokat. Az új közfoglalkoztatási rendszerben a munkaügyi kirendeltségek kiemelt szerepet kaptak. Szoros együttmüködést és folyamatos párbeszédet feltételez a foglalkoztatók részéről, hiszen a szociálisan hátrányos helyzetủ álláskeresőkről való gondoskodás közös felelősségen alapul. A közfoglalkoztatás csak a munkaügyi kirendeltségek közvetítésével valósulhat meg.

2011. év közepétől a közfoglalkoztatás szakmai irányítása átkerült a Belügyminisztériumhoz (BM). A BM számos programot dolgozott ki a közfoglalkoztatás minél hatékonyabb alkalmazására. A 2012-es év újból mérföldkő volt a közfoglalkoztatás rendszerében, mivel azok a mintaprogramok, amelyeket a 2011. év során dolgoztak ki, érdemben 2012 januártól indultak el. A kidolgozott programok a következök:

1. mezőgazdasági program,

2. mezőgazdasági utak rendbetétele,

3. belvízelvezetés,

4. illegális hulladéklerakó helyek felszámolása,

5. a közfoglalkoztatottak téli és egyéb értékteremtő foglalkoztatásának kialakítása,

6. bio- és megújuló energiatermelés,

7. belterületi közúthálózat javítása,

8. helyi sajátosságokra épülő programok.

A fenti programok 2013. évben újra indultak a közfoglalkoztatók kérelme alapján. Hatásukat tekintve összetettek: a közösségformálás, a települések és azok közvetlen környékének élhetőbbé, lakhatóbbá tétele, a lakosság szubjektív biztonságérzetének növelése, a közbiztonság javítása. A foglalkoztatás napi nyolcórás munkaidőben történik. A támogatások hozzájárulnak az önkormányzatok intézményeinek hatékonyabb müködtetéséhez és szervezetei önellátásának kialakításához. A kistérségi startmunka-mintaprogramok esetében a bér és járulék 100\%-os támogatásán kívül a beruházási és dologi költségek és kiadások teljes egészében támogathatók (I5).

2011. évtől a közfoglalkoztatási munkaviszonyt kiemelték a Munka Törvénykönyve alól. Ez a közfoglalkoztatási bért a minimálbér alá süllyesztette (Kulinyi 2013). Alacsonyabb bért kaphat csak a dolgozó, mert annak mértéke maximalizálva van. A 170/2011. (VIII.24.) Kormányrendelet a közfoglalkoztatási bér és a közfoglalkoztatási garantált bér megállapításáról, alapján a jelenlegi közfoglalkoztatási rendszerben azok az álláskeresők, akiket a végzettséget nem igénylő munkakörbe vonnak be - a tevékenység jellegére való tekintettel - a közfoglalkoztatási bért, akiket szakképzettséget igénylő munkakörbe vesznek fel, ők a közfoglalkoztatási garantált bért kaphatják. A nevezett kormányrendelet 2013. január 1-jén hatályos állapota szerint a közfoglalkoztatónak lehetősége van arra, hogy a programokban alkalmazott munkavezetők bérét magasabb, a rendelet által 
meghatározott maximum összegben állapítsák meg. Ez alacsonyabb, mint ami a munkatörvénykönyv szerint járna a dolgozónak az elsődleges munkaerőpiacon.

Csoba (2010a) kutatásában hangsúlyozza azt is, hogy a közfoglalkoztatási programokban elvégzett munkák nem mindegyike felel meg annak a közfoglalkoztatási programokkal szemben támasztott elvárásnak, hogy az segítse elő az álláskereső minél előbbi visszatérését az elsődleges munkaerőpiacra.

A társadalom, a gazdaság és az egyén szempontjait is figyelembe véve fontosabb a társadalom munkaképes tagjai számára munkalehetőséget teremteni közvetlen, vagy közvetett úton, mint segélyezni. A munkahelyet nemcsak anyagi vonatkozásban nem pótolják a pénzbeli támogatások, hanem egzisztenciális vonatkozásban sem.

Hazánkban közfoglalkoztatottként olyan természetes személy foglalkoztatható, aki a Munka Törvénykönyvének rendelkezései szerint munkaviszonyt létesíthet, és aki a munkaügyi kirendeltségen nyilvántartott álláskereső, vagy rehabilitációs járadékban részesül. Közfoglalkoztatási jogviszony - a normál munkaviszonytól eltérően - csak határozott időre létesíthető, próbaidő kikötése nélkül.

Közfoglalkoztatás - az általam bemutatni kívánt munkaerö-piaci eszközzel - az állam a foglalkoztatás elősegítését, bỏvítését tủzte ki célul a gazdaságilag elmaradott térségekben. A közfoglalkoztatásba bevont álláskeresők egyre nagyobb számával függ össze az a tény, hogy a hátrányos helyzetü térségeket a 2008. évi gazdasági válság nem sújtotta olyan mértékben, mint az ország fejlettebb régióit. Ezekben a régiókban nem nőtt olyan mértékben a munkanélküliek száma, sőt egyes térségekben még csökkent is. A közfoglalkoztatás és a válság miatt bekövetkezö állásvesztés sem földrajzilag, sem strukturálisan nem fedte le egymást. Míg a közfoglalkoztatásban az ország északi, északkeleti részében élö, képzetlenebb munkaerő vett részt nagyobb arányban, az „új” munkanélküliek jelentős hányada az ipar nagyobb foglalkoztatási súlya jellemezte dunántúli megyék középfokú végzettségüinek köréböl került ki, akik jövőjüket továbbra is a „normál” munkaerőpiacon képzelték el. A területi diszkrepancia hozzájárult ahhoz, hogy a válság következményeként a megyék, régiók foglalkoztatási és munkanélküliségi rátáját jellemző különbségek csökkenjenek. Az évek óta rosszabb helyzetben lévő megyék, régiók mutatói kevésbé, a kedvezőbb helyzetűeké viszont erőteljesen romlottak (I1).

A közfoglalkoztatást, a megbomlott munkaeröpiaci egyensúly átmeneti stabilizálásának eszközeként az állam mindig akkor alkalmazza kiemelten, amikor a munkaerőpiaci kereslet és kínálat egymáshoz viszonyított aránya jelentősen megbomlik. Ez leginkább akkor fordul elö, amikor egy gazdasági, foglalkoztatási rendszer alapjaiban megváltozik, és ez a munkahelyek tömeges megszünését okozza. Az utcára kerülő embereknek ezzel a foglalkoztatási formával egyrészt pótolták a kieső jövedelmet, mely az önfenntartó képességük megőrzését biztosítja, másrészt a rájuk eső közösségi feladatok ellátását oldották meg (Csoba 2010a). 


\section{MUNKAERŐPIACI VÁLSÁGKEZELÉS AZ EURÓPAI UNIÓ ORSZÁGAIBAN}

A gazdasági válság kialakulásával összefüggésben, az unió egyes országaiban eltérő hangsúlyt kapott a közfoglalkoztatás, mint a munkaeröpiaci válságkezelés eszköze, és az arra fordított pénzeszközök is eltérö nagyságot mutatnak. Egyes tagországokban jelentősen megnőtt a közfoglalkoztatottak száma, mint például Magyarországon, Lettországban, Franciaországban és Portugáliában. Ezzel egyidejüleg Németországban, Bulgáriában, Szlovákiában és Romániában nagymértékben csökkent a bevontak száma. Ugyan annak a problémának a kezelése nemzet specifikus jelleget kapott. Ezeket fontosnak tartom bemutatni annak érdekében, hogy a magyarországi közfoglalkoztatási rendszer megítélését nemzetközi viszonylatba helyezve is segítsem. Az egyes országok modelljei, közfoglalkoztatási formái igen nagy változatosságot mutatnak, közöttük számos eltérés tapasztalható. Koltai (2013) alapján bemutatott válságkezelő programokat összehasonlítom a magyarországi közfoglalkoztatási rendszerrel, és feltárom a fellelhető egyezőségeket és különbözőségeket. A különböző nemzetek programjainak egységes jellemzöje, hogy több célt szolgálnak, de hogy melyikre helyezik a hangsúlyt, abban eltérést mutatnak. A közfoglalkoztatási program pontos céljának megfogalmazása rendkívül fontos, hiszen a várt eredményt is ehhez lehet igazítani.

A válság az európai országok közül Lettországot érintette a legsúlyosabban. A hirtelen és óriásira duzzadó munkanélküliség kezelésére a lett kormány megindította a Válságkezelő Közmunkaprogramot. A program célja volt egyrészt munkajövedelmet biztosítani a munkanélküli ellátásból kiszorulók számára, valamint a munkához kapcsolódó készségek szinten tartása a válság idejére, annak érdekében, hogy a munkaerőpiaci folyamatok stabilizálódásakor az érintetteknek az elsődleges munkaerőpiacra történő visszatérésük sikeresebb legyen. A lett kormány által indított program, a magyar közfoglalkoztatási programtól való különbözősége abban nyilvánul meg a leginkább, hogy a foglalkoztatottak nem munkaszerződéssel, hanem együttmüködési megállapodás alapján vesznek részt a foglalkoztatásban. Ennek következtében a közfoglalkoztatás ideje nem vehető figyelembe a szolgálati idő kiszámításánál, biztosítási jogviszonynak sem minősül a nyugdíj szempontjából, és álláskeresési ellátásra sem szerez jogosultságot a foglalkoztatott. Hasonlóság a lett és a magyar közfoglalkoztatási rendszer között az, hogy a közfoglalkoztatásban dolgozók, a minimálbérnél alacsonyabb bér ellenében dolgoznak azért, hogy a program nehogy a nyílt munkaeröpiac ellenösztönzöjeként hasson.

Közösségi Munka Program néven indult az 1990-es évektől Csehországban az a közfoglalkoztatási program, melynek célja, a bevontak munkaszocializációjának fenntartása. Különbség a magyar és a cseh program között az, hogy míg a hazai közfoglalkoztatásban cél, hogy minél több személyt vonjanak be, ezért ugyanazon dolgozó ismételt bevonása nem javasolt, addig a cseh közfoglalkoztatásban résztvevők akár többször is részt vehetnek egymás után. Hasonlóság a két ország 
programjában az, hogy akik visszautasítják a közfoglalkoztatásban való részvételt, azoktól megvonják az álláskeresési ellátást.

A finn rendszer is szem elött tarja azt, hogy akik már részt vettek támogatott foglalkoztatásban, hat hónapig ismételten ne vehessenek részt. Azért nem adnak rá lehetöséget, hogy az álláskeresök folyamatosan támogatott foglalkoztatásban vegyenek részt, mert kutatási eredmények azt mutatják, hogy a támogatott foglalkoztatás ciklikus rendszerében való részvétel nem javítja a résztvevők munkaerőpiaci helyzetét, de a munka világától legtávolabb maradókat aktivitásra ösztönzi.

Görögországban, az országot igen súlyosan érintő válság hatásainak enyhítésére két közfoglalkoztatási program indult. A Helyi Munkahelyteremtést Szolgáló Közfoglalkoztatási Program, a helyi non-profit szervezeteket, non-profit szolgáltatásokat hivatott támogatni. Regisztrált álláskeresők elhelyezkedéséhez járul hozzá, különös tekintettel a tartósan munka nélkül lévőkre és az ellátás nélkül maradókra, valamint a 30 év alatti fiatalokra. A Munkanélküliek Minősítési Listáján Alapuló Közszolgáltatási Program keretében a közszféra szervezetei, közöttük az önkormányzatok és non-profit szervezetek - kapnak lehetőséget arra, hogy a munkaügyi szervezet által kiközvetített munkanélküliek közül válasszák ki munkavállalóikat. Ennek a programnak az a sajátossága, hogy a résztvevőket egy úgynevezett prioritási listáról választják ki. A munkanélküliek kérhetik a felvételüket a listára és megnevezhetnek három foglalkoztatót, ahol szívesen dolgoznának. A munkaügyi szervezet minden álláskeresőt pontoz, hátrányos helyzet alapján. Ehhez plusz pont adódik a munkanélküliség hosszával összefüggésben, az 55. életév betöltése okán, a 29 év alatti életkor vagy az eltartott gyerekek számának kapcsán. Ezzel a munkaügyi szervezetnek az a célja, hogy a közfoglalkoztatási programokba a priorizált csoportokba tartozók kerülhessenek be. Itt hasonlóság fedezhető fel a magyar munkaügyi szervezet kategorizálási rendszerével. Technikailag, a magyar munkaügyi szervezet nyilvántartási rendszerében is müködik egy úgynevezett kategorizálás. Az ügyfelek a nyilvántartásba vételkor - meghatározott prioritások alapján - kategorizálásra kerülnek, azonban a gyakorlatban való alkalmazása és hasznosulása még nem jár ennyire elöre, mint a görög rendszerben. A prioritások a következök: alapfokú iskolai végzettség, fogyatékkal élő, 55 év feletti, 25 év alatti, tartósan álláskereső, veszélyeztetett.

A horvát közfoglalkoztatási programokban - hasonlóan a hazai rendszerhez jellemzöen a helyi önkormányzatok, közintézmények és az önkormányzattal ellátási szerződéssel rendelkező non-profit szervezetek lehetnek a foglalkoztatók. $\mathrm{Az}$ elvégzendő feladatok és a betöltendő munkakörök szinte teljes egyezőséget mutatnak a magyarországi, huzamosabb idejü közfoglalkoztatási programokkal. A munkakörök a közfeladatok ellátásához kötődnek.

Az ír közfoglalkoztatás sajtossága a projektszerüség. A bevont álláskeresők csak úgy, mint Magyarországon - határozott ideig, részmunkaidőben dolgozhatnak egy meghatározott projektben. A magyar közfoglalkoztatási programtól jelentős eltérés tapasztalható abban, hogy a résztvevők munkaviszonya egyszer 
meghosszabbítható. Erre Magyarországon nincs lehetőség. A 2011. évi CVI. Törvény szerint a közfoglalkoztatási jogviszony csak határozott időre létesíthető. A határozott idő nem lehet hosszabb, mint a közfoglalkoztatás támogatásáról szóló jogszabály alapján nyújtott támogatásról szóló hatósági szerződésben elöírt időtartam. Az ír közfoglalkoztatásnak nem célja a munkaerőpiaci reintegráció, ezért nem kapcsolódik hozzá képzés. A közfoglalkoztatáshoz kapcsolódó képzés Magyarországon is csak a mezögazdasági programokban kötelező feltétele a program megvalósíthatóságának. A Közösségi Elhelyezkedési Programban, amelyet 2010-ben a válság hatására vezettek be, ismételten megjelenik a magyar rendszerhez hasonlóan a kötelező jellegüség. Aki azt visszautasítja, a segélyének az elvesztésével jár.

Portugáliában két rendkívül népszerủ program helyettesíti a közfoglalkoztatási programot, a Foglalkoztatási Integrációs Szerződés+. A résztvevők - csak úgy, mint Magyarországon - közfeladatot látnak el, és a foglalkoztatók a helyi önkormányzatok és non-profit civil szervezetek lehetnek. A két program közötti különbség mindösszesen a bevonhatók, a célcsoportok körében nyilvánul meg. Míg az elsőben csak az álláskeresési ellátásban részesülők lehetnek foglalkoztatottak, addig a másodikban csak a szociális segélyben részesülők foglalkoztathatók. A bevonhatók körére való tekintettel, összehasonlítva a hazai közfoglalkoztatási programokkal, azt látjuk, hogy a magyarországi közfoglalkoztatási programok bármelyikénél elsődleges szempont az, hogy regisztrált álláskereső legyen az ügyfél. Az országos közfoglalkoztatási programoknál egyéb kötelezö kitétel nincs is. A további programok esetében a startminta programokban illetve az önkormányzati huzamosabb idejű közfoglalkoztatási programokban elsődlegesen a foglalkoztatás helyettesítő támogatásban részesülők, az ellátatlanokat, valamint a rehabilitációs ellátásban részesülők foglalkoztathatók.

A román közfoglalkoztatási programok már az 1990-es évek vége óta müködnek. Az országot is súlyosan érintő válság ellenére az erre fordítható összeg csökkenése miatt a bevontak létszáma csökkent. Azokban a legszegényebb térségekben indítottak csak közfoglalkoztatási programokat, ahol más egyéb munkalehetőség nem volt. Az elvégzendő feladatokat tekintve egyezőséget mutat más ország programjaival, mivel itt is a közfeladatokhoz kötődnek, és a foglalkoztatók az önkormányzatok. Eltérések a programok finanszírozásában lelhetök fel (Koltai 2013).

Ausztriában a közmunka, mint foglalkoztatási forma nem müködtethetö. Senkit nem lehet közmunkára kényszeríteni. Mint már a magyar közérdekü foglalkoztatás rendszerénél említettem, Ausztriában is van arra lehetőség, hogy bizonyos büntetések esetén az elítélt ledolgozza a rá kirótt bírságot, szociális vagy kommunális munkával.

Angliában ismeretlen a kényszerrel végzett közmunka, amelyért a minimálbér felének megfelelö összeget fizetnek. A munkanélkülieknek 13 hét munkanélküliség után kötelező részt venni az aktív álláskeresést segítő programokban, a segély megtartása érdekében. 
Franciaországban,- mint Ausztriában - ismételten csak az a fajta közmunka jelenik meg, amely büntetési tételként ismert, és amelyet kisebb vétség esetén szabhatnak ki az elkövetöre. A kötelezö közmunka bevezetése a 2012-es évhez kapcsolódik.

Oroszországban a közmunka az egyes válság sújtotta területeken az egyetlen megélhetési forrás. Csak a munkanélküliként regisztráltak vehetnek benne részt, előnyt élveznek a munkanélküli segélyböl kiesettek. Határozott idejű szerződés szabályozza, az elsődleges munkaerőpiacon történő elhelyezkedés esetén azonnal felbontható (Bujáki 2011, Oláh 2012).

\section{4. ÖSSZEGZÉS}

A közfoglalkoztatás különböző formában és funkcióban végig jelen volt és van a középkorban és az újkorban is. Azokban a korszakokban kapott nagyobb hangsúlyt, melyekben a munkaeröpiaci kereslet-kínálati egyensúly hiánya következtében kialakult jövedelemhiány kikényszerítette a központi hatalom beavatkozását. A kötelezö közmunkának fontos szerepe volt a szegények fegyelmezésében, alacsony társadalmi helyük kijelölésében. Napjainkban a közfoglalkoztatás célja a munkaeröpiaci esélyek növelése érdekében halmozottan hátrányos helyzetü álláskeresők - foglalkoztatást helyettesítő támogatásban részesülö, álláskeresési és szociális ellátásra nem jogosult - foglalkoztatása. Fontos eszköz a közfoglalkoztatás a természeti és épített környezet védelmében, a közétkeztetés minőségének javításában, az önfenntartó települések kialakításában, a rendezett közösségi terek, élhetö települések megvalósításában. A közfoglalkoztatás feladata napjainkban is összetett. Úgy gondolom, hogy a munkanélküliség problémáját nem lehet csak a közfoglalkoztatással megoldani, csupán mérsékelni. Az előzőeken kívül az adó- és járulékfizetés rendszere, a nyugdíjrendszer, a megváltozott munkaképességü személyek ellátásának a rendszere, a szociális ellátások rendszere is jelentősen befolyásolja mind a munkanélküliségi ráta, mind a foglalkoztatottsági szint alakulását. Ezek szabályozása a törvényhozók feladata, az ő feladatuk megteremteni azokat a feltételeket, hogy minden ember élni és boldogulni tudjon a hazájában.

\section{IRODALOMJEGYZÉK}

Bácsné Bába É. (2014): Kisgyermekes anyák a munkaeröpiacon - Pro és contra. TAYLOR, Gazdálkodás és Szervezéstudományi Folyóirat. A Virtuális Intézet Közép-Európa Kutatásáért Közleményei, VI. évf. 1-2. 2014. pp. 250-259.

Bagó J. (2013): A közfoglalkoztatás célja és szabályozása. Munkaügyi Szemle. 2013/ 1. szám. pp.4-5.

Bass L. (2010): Az „Út a Munkához”program hatása - egy kérdőíves felmérés tapasztalatai. Esély. 21. évf. 1. sz. pp. 46-65.

Bujáki A. (2011): Ásóval, lapáttal a világ ellen, 168 Óra. XXIII. évf. 44. sz. pp. 30-33.

Cloke, P. J. - Park, C. C. (1985): Rural Resource Management. Croom Helm, London.

Czomba S. (2010): Nemzeti Közfoglalkoztatási Program címủ előadás 2010.10.26. Szolnok

Csehné P. I. (2007): A közhasznú foglalkoztatás jogi és humán vonatkozású változásai az utóbbi tíz évben. Munkaügyi Szemle. 2007. március. pp. 23-27. 
Csoba J. (2010a): Segély helyett munka. In. A közfoglalkoztatás formái és sajátosságai. Szociológiai Szemle. 1. sz. pp. 26-52.

Csoba J. (2010b): A közfoglalkoztatás régi-új rendszere. Útközben az „Út a munkához program”. Esély. 1. sz. pp. 4-24.

Firle R. - Scharle Á. - Szabó P. A. (2007): A rendszeres szociális segély munkakínálati hatása. In. Közelkép, jóléti ellátások és munkakínálat. (szerk.) Cseres-Gergely Zs. - Scharle Á. MTA Közgazdaságtudományi Intézet, $\quad$ Budapest, $\quad$ pp. 75-90. http://econ.core.hu/file/download//MT07kozel.pdf

Galas I. P. - Nagy Gy. (2003): A szigorítások hatása a munkanélküliek elhelyezkedési ütemére. In. A munkanélküli-ellátási rendszer átalakításának hatásvizsgálat keretében végzett kutatások eredményeiröl. Kutatási összefoglaló, MTA Közgazdaságtudományi Kutatóközpont, Munkaerőpiaci Kutatások Műhelye, BKÁE Emberi Erőforrás Tanszék, Foglalkoztatási Hivatal, Budapest, pp. 155-202.

Gyáni G. (2011): Közmunka a Horthy-korban: Az állami szociálpolitika megoldási kísérletei. História. 33. évf. 7. sz. pp. 30-33.

Hoffman I. (2012): A közfoglalkoztatás múltja és jelen Magyarországon. Belügyminisztérium. Közfoglalkoztatási Helyettes Államtitkárság.

Hudomiet P. - Kézdi G. (2008): Az aktív munkaerőpiaci programok nemzetközi tapasztalatai. Kormányzás, Közpénzügyek, Szabályozás. 3. évf. 1. sz. pp. 3-37. http:/www.kormanyzas.hu/081/01_Hodomiet-Kezdi.pdf

Kézdi G. (2011): Foglalkoztatáspolitikai programok hatásvizsgálata. In. Munkaerőpiaci Tükör 2011. MTA Közgazdaságtudományi Intézet, Budapest, pp. 41-72.

Kis K. (2008): A Hódmezővásárhelyi kistérség humán erőforrásainak hierarchia-rendszerü vizsgálata. Agrártudományi Közlemények, 2008/29. pp. 91-110.

Koltai L. (2013): A közfoglalkoztatás szerepe válság idején az európai országokban. Munkaügyi Szemle. 1 sz.. pp. $27-38$.

Kulinyi M. (2013): A közfoglalkoztatás változó céljai. /,Kígyónak lábsó” avagy utazás a közfoglalkoztatás céljai körül/ Munkaügyi Szemle. 1. sz. pp. 17-26.

Oláh J. (2012): A közfoglalkoztatás, mint a munkanélküliség csökkentésének eszköze. Munkaügyi Szemle Stúdium. szeptember pp. 1-10.

Semjén A. (1996): a pénzbeli jóléti támogatások ösztönzési hatásai. Közgazdasági Szemle. 43. évf. 10. sz. pp. 841-862.

Ulicska L. (1997): A munka mint büntetés. Esély. 3 sz. pp. 86-91.

Vántus A. (2010): A foglalkoztatottság jellemzőinek változása Hajdú-Bihar megyei állattenyésztő gazdaságokban. IV. Régiók a Kárpát-medencén innen és túl konferencia. Virtuális Intézet Közép-Európa Kutatására Közleményei. II. évf. 2-3. sz. (No. 3-4.) pp. 24-31.

1991. évi IV. Törvény a foglalkoztatás elösegítéséröl és a munkanélküliek ellátásáról

1993. évi III. Törvény a szociális igazgatásról és szociális ellátásokról

1997. évi LXXX. Törvény a társadalombiztosítás ellátásaira és a magánnyugdíjra jogosultakról, valamint e szolgáltatások fedezetéről

6/1996. (VII. 16.) MüM rendelet a foglalkoztatást elösegítő támogatásokról, valamint a Munkaerőpiaci Alapból foglalkoztatási válsághelyzetek kezelésére nyújtható támogatásról

49/1999. (III. 26.) Kormányrendelet a közmunkaprogramok támogatási rendjéröl

30/2000. (IX.15) GM rendelet a munkaerőpiaci szolgáltatásokról, valamint az azokhoz nyújtható támogatásokról

2010. évi CLXXI. Törvény egyes szociális, gyermekvédelmi, családtámogatási, fogyatékosságügyi és foglalkoztatási tárgyú törvények módosításáról

375/2010. (XII. 31.) Kormányrendelet a közfoglalkoztatáshoz nyújtható támogatásokról

212/2010. (VII. 1.) Kormányrendelet az egyes miniszterek, valamint a Miniszterelnökséget vezetö államtitkár feladat- és hatásköréről

2011. évi CVI. Törvény a közfoglalkoztatásról és a közfoglalkoztatáshoz kapcsolódó, valamint egyéb törvények módosításáról 
170/2011. (VIII. 24.) Kormányrendelet a közfoglalkoztatási bér és a közfoglalkoztatási garantált bér megállapításáról

Internet 1: A közcélú foglalkoztatás kibővülésének célzottsága, igénybevétele és hatása a tartós munkanélküliségre. Kutatási jelentés, 2011. augusztus 30. Budapest Szakpolitikai Intézet és Hétfa Elemző Központ, Budapest http://www.budapestinstitute.eu/uploads/BI_kozcelu_kut_jelentes_2011aug30.pdf; _ Letöltés ideje: 2013. március 9.

Internet 2: Aktív foglalkoztatáspolitikai eszközök - Mai magyar szociálpolitika- 8. téma http://users.atw.hu/deszocpol/mai_magyar_szocialpolitika/kesok/aktiv_foglalkoztataspolitikai_e szkozok_czine_tunde.doc; Letöltés ideje: 2013. február 8.

Internet 3: Állami Számvevőszék: 2007. Jelentés a közmunkaprogramok támogatására fordított pénzeszközök hasznosulásának ellenörzéséröl. http://www.asz.hu/jelentes/0732/jelentes-akozmunkaprogramok-tamogatasara-forditott-penzeszkozok-hasznosulasanakellenorzeserol/0732j000.pdf; Letöltés ideje: 2013. február 8.

Internet 4: Aktív munkaerőpiaci politikák komplex értékelése kutatáshoz Önkormányzati felmérés készítése és értékelése. http://internet.afsz.hu/resource.aspx?ResourceID=tamop_131_strategia_3.2_onkormanyzati; Letöltés ideje: 2013. március 15.

Internet 5: Aktív foglalkoztatáspolitikai eszközök müködtetése 2011-ben. http://nfsz.munka.hu/engine.aspx?page=full_AFSZ_A_foglalkoztataspolitikai_eszkozok_mukod ; Letöltés: 2013. március 19. 